\title{
Effects of aluminum sulfate on delta-aminolevulinate dehydratase from kidney, brain, and liver of adult mice
}

M.R.C. Schetinger,

C.D. Bonan, V.M. Morsch,

D. Bohrer, L.M. Valentim

and S.R. Rodrigues
Departamento de Q uímica, Centro de Ciências Naturais e Exatas, Universidade Federal de Santa Maria, Santa M aria, RS, Brasil

\section{Correspondence \\ M.R.C. Schetinger \\ Departamento de Química \\ Centro de Ciências Naturais \\ e Exatas, UFSM \\ 97105-900 Santa Maria, RS \\ Brasil \\ Fax: + 55-55-220-8031 \\ E-mail: mrosa@base.ufsm.br}

Research supported by CNPq, CAPES, and FIPE-UFSM. M.R.C. Schetinger is the recipient of a CNPq fellowship (No. 524365/96.2).

Received September 24, 1998 Accepted March 16, 1999

\section{Abstract}

The purpose of the present study was to investigate the in vitro and in vivo effects of aluminum sulfate on delta-aminolevulinic acid dehydratase (ALA-D) activity from the brain, liver and kidney of adult mice (Swiss albine). In vitro experiments showed that the aluminum sulfate concentration needed to inhibit the enzyme activity was $1.0-5.0 \mathrm{mM}$ $(\mathrm{N}=3)$ in brain, 4.0-5.0 $\mathrm{mM}(\mathrm{N}=3)$ in liver and 0.0-5.0 $\mathrm{mM}(\mathrm{N}=3)$ in kidney. The in vivo experiments were performed on three groups for one month: 1) control animals ( $\mathrm{N}=8) ; 2)$ animals treated with $1 \mathrm{~g} \%$ $(34 \mathrm{mM})$ sodium citrate $(\mathrm{N}=8)$ and 3$)$ animals treated with $1 \mathrm{~g} \%(34$ $\mathrm{mM})$ sodium citrate plus $3.3 \mathrm{~g} \%(49.5 \mathrm{mM})$ aluminum sulfate $(\mathrm{N}=8)$. Exposure to aluminum sulfate in drinking water inhibited ALA-D activity in kidney $(23.3 \pm 3.7 \%$, mean \pm SEM, $\mathrm{P}<0.05$ compared to control), but enhanced it in liver $(31.2 \pm 15.0 \%$, mean \pm SEM, $\mathrm{P}<0.05$ ). The concentrations of aluminum in the brain, liver and kidney of adult mice were determined by graphite furnace atomic absorption spectrometry. The aluminum concentrations increased significantly in the liver $(527 \pm 3.9 \%$, mean $\pm \mathrm{SEM}, \mathrm{P}<0.05)$ and kidney $(283 \pm 1.7 \%$, mean $\pm \mathrm{SEM}, \mathrm{P}<0.05)$ but did not change in the brain of aluminum-exposed mice. One of the most important and striking observations was the increase in hepatic aluminum concentration in the mice treated only with $1 \mathrm{~g} \%$ sodium citrate $(34 \mathrm{mM})(217 \pm 1.5 \%$, mean $\pm \mathrm{SEM}, \mathrm{P}<0.05$ compared to control). These results show that aluminum interferes with delta-aminolevulinate dehydratase activity in vitro and in vivo. The accumulation of this element was in the order: liver $>$ kidney $>$ brain. Furthermore, aluminum had only inhibitory properties in vitro, while in vivo it inhibited or stimulated the enzyme depending on the organ studied.

\section{Introduction}

Aluminum was thought to be nontoxic in the past. However, recent data have raised serious questions about the hazards of this metal $(1,2)$. Aluminum salts administered by
Key words

- Aluminum sulfate

- Aluminum determination

- Delta-aminolevulinate dehydratase different routes can produce toxic effects in animal models (3-5) some of which involve alterations in enzymatic activities $(6,7)$. It is presently accepted that aluminum intoxication may induce anemia and encephalopathy in humans and animals (8). Touam and 
collegues (9) and Kaiser and Schwartz (3) proposed that aluminum may cause microcytic anemia by a direct effect on heme biosynthesis, specifically alterations in the activity of delta-aminolevulinic acid dehydratase (ALA-D, E.C. 4.2.1.24). ALA-D is a sulfhydryl-containing enzyme that is inhibited by heavy metals and sulfhydryl reagents (10-16) and seems to be the principal leadbinding protein in human erythrocytes (17). The toxic effects of aluminum on ALA-D may involve protein synthesis, enzyme inhibition or enzyme activation (18).

ALA-D inactivation may lead to an accumulation of delta-aminolevulinic acid (substrate) that can cause an overproduction of reactive oxygen species which, in turn, could explain the toxic effects of metals $(19,20)$. In view of the pro-oxidant effect of ALA, a study of the inhibition of ALA-D by aluminum can contribute to a better understanding of the toxicology of this metal. These processes may contribute to oxidative stress in cells and may be related to degenerative cellular mechanisms.

The main purpose of the present study was to investigate the in vitro and in vivo effects of aluminum sulfate on delta-aminolevulinic acid dehydratase in the brain, liver and kidney and the aluminum deposition in these organs of adult mice.

\section{Material and Methods}

\section{Animals}

Mice of both sexes weighing 25-30 g from our breeding colony were used. The animals were maintained in an air-conditioned room $\left(22-25^{\circ} \mathrm{C}\right)$ under natural lighting conditions and housed eight to a cage.

\section{Material}

Delta-aminolevulinic acid (ALA), albumin and Coomassie blue were purchased from Sigma Chemical Co. (St. Louis, MO,
USA), and nitric acid from Merck (Darmstadt, Germany). All other chemicals used in this study were of the highest purity available.

\section{Treatment}

The in vivo experiments were performed over a period of one month with the substances supplied in the drinking water ( $a d$ libitum). The animals were divided into three groups: 1) control animals;2) animals treated with $1 \mathrm{~g} \%(34 \mathrm{mM})$ sodium citrate, and 3) animals treated with $1 \mathrm{~g} \%(34 \mathrm{mM})$ sodium citrate plus $3.3 \mathrm{~g} \%(49.5 \mathrm{mM})$ aluminum sulfate. These concentrations were used according to previous results obtained in our laboratory (data not shown). Sodium citrate was added because complex formation between $\mathrm{Al}^{3+}$ and dietary citrate may facilitate absorption or tissue retention, or both (21). Food and water intake was measured daily. The treatment did not affect food or water intake by the animals. All solutions were administered from plastic bottles.

\section{Contamination control}

To avoid metal contamination, only plastic material was used. All material (pipette tips, volumetric flasks) was left at least $48 \mathrm{~h}$ in a 1:9 $\mathrm{HNO}_{3} /$ ethanol mixture $(\mathrm{v} / \mathrm{v})$ and washed with Milli-Q water shortly before use (22). Animal decapitation and manipulation and sample and reagent preparations were carried out on a class Trox clean bench class 100.

\section{Sample preparation and biochemical assay}

Mice were anesthetized with ether and killed by decapitation. Liver, brain and kidney were rapidly dissected and immediately placed on ice. Liver was homogenized in 7 volumes, kidney in 5 volumes and brain in 2 volumes of $150 \mathrm{mM} \mathrm{NaCl}$ with ten up-anddown strokes at approximately $1200 \mathrm{rev} / \mathrm{min}$ 
in a Teflon-glass homogenizer. The homogenate was centrifuged at $4000 \mathrm{~g}$ at $4^{\circ} \mathrm{C}$ for 10 min to yield a low-speed supernatant fraction that was used for enzyme assay.

For the in vitro assays, aluminum sulfate stock solution $(50 \mathrm{mM})$ was prepared in deionized water, stored in plastic containers and used for a period of two weeks. The dilute solutions were prepared fresh daily.

ALA-D activity was assayed according to the method of Sassa (23) by measuring the rate of porphobilinogen formation, except that the incubation medium for the aluminum sulfate assays contained $45 \mathrm{mM}$ sodium phosphate buffer, $\mathrm{pH}$ 5.5. Phosphate buffer was used in these experiments because suitable enzyme activity was not obtained when citrate buffer was used (data not shown). The $\mathrm{pH}$ of the incubation medium was 5.5 to avoid problems with aluminum hydrolysis and precipitation as $\mathrm{Al}(\mathrm{OH})_{3}$ (24). In all enzyme assays, the final concentration of ALA was $2.2 \mathrm{mM}$. The product of reaction was determined with modified Ehrlich reagent at $555 \mathrm{~nm}$ using a molar absorption coefficient of $6.1 \times 10^{4} \mathrm{M}^{-1} \mathrm{~cm}^{-1}$ (23) for the Ehrlich-porphobilinogen salt. Incubation was started by adding $150 \mu \mathrm{l}$ of the tissue preparation. The final volume of the incubation medium was $250 \mu$ l. Protein concentration was measured by the method of Bradford (25).

\section{Aluminum determination}

To measure the aluminum content in the samples, a $1000 \mathrm{mg} / \mathrm{l}$ aluminum stock solution was prepared from aluminum nitrate (Merck) in water and standard solutions were prepared by appropriate dilution of the aluminum stock solution. Nitric acid was further purified by sub-boiling distillation. Water was distilled, deionized and further purified with a Millipore system. Samples were placed in previously weighed flasks and 2.5 $\mathrm{ml}$ nitric acid was added for brain and kidney or $5.0 \mathrm{ml}$ for liver digestion and aluminum solubilization. The flasks were tightly closed and maintained at room temperature for $72 \mathrm{~h}$ for complete sample digestion. The samples were diluted with water $(1: 1)$. The aluminum concentration was measured with a Varian SpectraAA atomic absorption spectrometer with a deuterium background corrector, a Varian GTA-100 graphite furnace and an auto sampler. Analyses were performed using pyrolytic graphite-coated tubes with L'vov platforms. The hollow cathode lamp was used at $10 \mathrm{~mA}$ at the $309.3 \mathrm{~nm}$ resonance line, the spectral slit width was set at $0.7 \mathrm{~nm}$, and the injection volume used was $5 \mu 1$. The pyrolysis and atomization temperature used were 1000 and $2500^{\circ} \mathrm{C}$, respectively; the absorbance signal was measured in the peak area and the purging gas used was argon, with stop flow at the time of atomization. A Trox clean bench class 100 and a Berghof BSP 929 sub-boiling distillation apparatus were used.

\section{Statistical analysis}

Data were analyzed by one-way analysis of variance followed by the Duncan test when the $\mathrm{F}$ test was significant $(\mathrm{P}<0.05)$ to determine the differences between the control and the other groups.

\section{Results}

\section{In vitro effect of aluminum sulfate on ALA-D activity}

ALA-D activity was measured in brain, liver and kidney homogenates of adult mice using increasing aluminum sulfate concentrations in the incubation medium (Table 1). Cerebral ALA-D activity decreased with 0.5 to $5.0 \mathrm{mM}$ of aluminum sulfate $(\mathrm{P}<0.05)$. ALA-D from liver was significantly inhibited by 4.0 and $5.0 \mathrm{mM}$ aluminum sulfate $(\mathrm{P}<0.05)$ and renal activity was inhibited by 1.0 to $5.0 \mathrm{mM}(\mathrm{P}<0.05)$ compared to the control group. 
Table 1 - In vitro effect of aluminum sulfate on delta-aminolevulinic acid dehydratase (ALA-D) from brain, liver and kidney of adult mice.

Data are reported as mean \pm SEM for at least three experiments. $* \mathrm{P}<0.05$ compared to control (Duncan test). ALA-D activity is reported as percent of control activity ( $0 \mathrm{mM}$ aluminum sulfate). The control enzyme activities were $38 \pm 1.0$ in brain, $238 \pm 13$ in liver and $74 \pm 6$ in kidney, reported as nmol porphobilinogen $\mathrm{h}^{-1} \mathrm{mg}$ protein ${ }^{-1}$.

\begin{tabular}{lccc}
\hline Aluminum $(\mathrm{mM})$ & Brain & Liver & Kidney \\
\hline Control & 100 & 100 & 100 \\
0.5 & $89 \pm 4.3^{*}$ & $87 \pm 12.1$ & $95 \pm 3.7$ \\
1.0 & $86 \pm 3.0^{*}$ & $90 \pm 6.0$ & $80 \pm 2.7^{*}$ \\
2.5 & $80 \pm 1.7^{*}$ & $92 \pm 15.6$ & $78 \pm 2.7^{*}$ \\
4.0 & $65 \pm 6.5^{*}$ & $50 \pm 3.8^{*}$ & $37 \pm 9.0^{*}$ \\
5.0 & $15 \pm 2.9^{*}$ & $12 \pm 1.2^{*}$ & $14 \pm 1.8^{*}$
\end{tabular}

Table 2 - In vivo effect of aluminum sulfate on delta-aminolevulinic acid dehydratase (ALA-D) from brain, liver and kidney of adult mice.

Data are reported as mean \pm SEM for at least five animals per group $* \mathrm{P}<0.05$ compared to control (Duncan test). ALA-D activity is reported as percent of control. The control enzyme activities were $32 \pm$ 2.7 in brain, $211 \pm 26$ in liver, and $88 \pm 14$ in kidney, reported as nmol porphobilinogen $\mathrm{h}^{-1} \mathrm{mg}$ protein ${ }^{-1}$.

\begin{tabular}{lccc}
\hline Groups & Control & Citrate & $\begin{array}{c}\text { Citrate }+ \\
\text { aluminum sulfate }\end{array}$ \\
\hline Brain & 100 & $90.2 \pm 6.0$ & $93.5 \pm 6.5$ \\
Liver & 100 & $148.3 \pm 19.0^{*}$ & $131.2 \pm 15.0^{*}$ \\
Kidney & 100 & $86.2 \pm 13.0$ & $76.7 \pm 3.7^{*}$
\end{tabular}

Table 3 - Tissue aluminum concentration determined by graphite furnace atomic absorption spectrometry (GFAAS).

Data are reported as $\mu \mathrm{g} / \mathrm{g}$ wet weight. $* \mathrm{P}<0.05$ compared to control (Duncan test); $* * \mathrm{P}<0.05$ compared to control and to the citrate group (Duncan test). Each result represents the mean for six animals and two determinations by GFAAS.

\begin{tabular}{lccl}
\hline Groups & Control & Citrate & $\begin{array}{c}\text { Citrate }+ \\
\text { aluminum sulfate }\end{array}$ \\
\hline Brain & $0.321 \pm 0.021$ & $0.291 \pm 0.013$ & $0.320 \pm 0.031$ \\
Liver & $0.639 \pm 0.054$ & $1.386 \pm 0.011^{*}$ & $3.368 \pm 0.037^{* *}$ \\
Kidney & $0.592 \pm 0.052$ & $0.502 \pm 0.027$ & $1.679 \pm 0.010^{* *}$
\end{tabular}

\section{In vivo effect of aluminum sulfate on ALA-D activity}

In vivo treatment with aluminum sulfate did not inhibit ALA-D activity in the brain homogenate (Table 2). In liver, treatment with citrate and aluminum plus citrate increased ALA-D activity by $30-40 \%$ when compared to the control group. In kidney, ALA-D activity was inhibited $24 \%$ in the aluminum plus citrate group when compared to the control group. There was no difference between the control and citrate groups.

\section{Aluminum measurement by graphite furnace atomic absorption spectrometry}

The distribution of aluminum in the organs is summarized in Table 3. Treatment did not increase aluminum concentration in brain. In liver, citrate and citrate plus aluminum caused an increase in aluminum concentration when compared to the control group, with a difference in aluminum concentration between these two groups. Finally, in kidney aluminum concentration was increased in the aluminum plus citrate group when compared to the control and citrate groups.

\section{Discussion}

This study shows that aluminum sulfate interferes with ALA-D activity in brain, liver and kidney of adult mice. There are several hypotheses for ALA-D inhibition by aluminum, one of them described by Zaman and colleagues (26), who proposed that aluminum inhibits ALA-D by attaching to the -SH group of the active site of the enzyme, thus reducing its activity. However, aluminum has low affinity for -SH groups (24) which makes a direct effect of aluminum on cysteinyl residues of ALA-D unlikely. Nevertheless, inhibition of ALA-D activity can contribute to increasing ALA accumulation which in turn can enhance generation of free radicals, aggravating oxidative damage to 
cell components (27). Thus, all these events can contribute to promoting aluminum toxicity in our treatment.

Aluminum sulfate inhibited brain ALA$\mathrm{D}$ activity in vitro but not in vivo (Tables 1 and 2), possibly because in our intoxication model aluminum did not accumulate in brain after in vivo exposure (Table 3). Our results agree with those reported by Garbossa and colleagues (28) who stated that prolonged treatment ( 15 weeks) with a high aluminum citrate concentration $(100 \mathrm{mmol} / \mathrm{l})$ did not result in a significant increase in brain aluminum content.

In vitro inhibition of the hepatic enzyme was observed only at high aluminum concentrations (higher than 4.0 mM). Based on the inhibitory effect of a high dose of aluminum it would be more reasonable to expect an inhibition of hepatic ALA-D after in vivo exposure. However, hepatic ALA-D activity of mice exposed to aluminum in drinking water was increased about $30-40 \%$ when compared to control groups. In addition, the activation caused by aluminum was probably related to an increase in aluminum concentration in this organ (Table 3 ).

The greater deposition of aluminum in liver observed in the present study is in accordance with the findings of Fiejka and colleagues (5) which showed that the liver is the main target organ for aluminum accumulation and toxicity. Presumably, the activation of hepatic ALA-D can be regarded as a manifestation of aluminum toxicity or as part of an adaptive hepatic response to aluminum accumulation.

It is interesting that citrate alone increased about 2-fold while citrate plus aluminum increased about 5-fold the accumulation of aluminum in liver (Table 3 ) even though the level of aluminum contamination in tap water used in the present study ( $25 \mathrm{ppb}$, or approximately $1 \mu \mathrm{M}$; data not shown) was about 5 orders of magnitude lower than the high $(49.5 \mathrm{mM})$ toxicologic level of aluminum in water administered to the aluminum plus citrate group. The increase in the hepatic levels of aluminum in animals drinking tap water supplemented with $1 \mathrm{~g} \%$ sodium citrate may be of toxicologic importance, since the human population consumes food and beverages containing citrate and drink water that contains aluminum in ranges similar to that observed in the present study (10).

In the kidney, aluminum inhibited ALA$\mathrm{D}$ after in vitro and in vivo treatment and the aluminum concentration was increased after in vivo exposure (Table 3 ). It is noteworthy that the levels of aluminum in kidney of exposed mice were considerably lower (60 $\mu \mathrm{M})$ than the concentration required to inhibit the renal enzyme in vitro $(1.0 \mathrm{mM})$. Consequently, the inhibition of the renal enzyme after in vivo exposure cannot be solely explained by aluminum accumulation in this organ. The inhibition of renal ALA-D by aluminum contrasts with the activation observed in liver. The opposite effect of aluminum on renal and hepatic ALA-D after in vivo exposure can be explained in terms of some protecting tissue-specific factor present in liver, but not in kidney. This consideration is supported in part by the in vitro results which showed that the renal enzyme tended to be more sensitive to the inhibitory effects of aluminum.

The inhibition of ALA-D may cause an increase in 5-aminolevulinic acid concentration that presumably enhances the production of free radicals in affected tissues $(19,20)$. Hepatic aluminum toxicity in our intoxication model possibly had no direct relationship with aminolevulinic acid accumulation because hepatic ALA-D was activated after exposure to aluminum (Tables 2 and 3 ). Alternatively, aluminum could interfere with iron disposition, making this metal more available to catalyze free radical production in liver (29). In contrast to liver, 5-aminolevulinic acid accumulation presumably plays a role in aluminum toxicity in the kidney because renal ALA-D is inhibited after aluminum exposure (Tables 2 and 3 ). 
An important observation of the present study was that citrate increases the aluminum deposition in the liver of mice. These findings are of considerable importance since a similar phenomenon could occur in hu- mans who consume citrate daily in the diet and are exposed to low levels of aluminum which are judged safe from a toxicologic point of view but may become toxic in the presence of citrate.

\section{References}

1. Boegman RJ \& Bates LA (1984). Neurotoxicity of aluminum. Canadian J ournal of Physiology, 62: 1010-1014.

2. LiuJ \& Nordberg GF (1996). Nephrotoxicities of aluminum and/or cadmium-metallothionein in rats: creatine excretion and metabolism of selected essential metals. Pharmacology and Toxicology, 77: 155-160.

3. Kaiser L \& Schwartz KA (1985). Aluminum-induced anemia. American J ournal of Kidney Diseases, 5: 348-352.

4. Liu J Nordberg GF \& Frech W (1996). Aluminum accumulation in some tissues of rats with compromised kidney function induced by cadmium-metallothionein. Pharmacology and Toxicology, 78: 289-295.

5. Fiejka M, Fiejka E \& Dlugaszek M (1996). Effect of aluminum hydroxide administration on normal mice: Tissue distribution and ultrastructural localization of aluminum in liver. Pharmacology and Toxicology, 78: 123-128.

6. Schetinger MRC, Wyse ATS, Silva LB, Barcellos CK, Dias RD \& Sarkis J J F (1995). Effects of aluminum chloride on the kinetics of rat cortex synaptosomal ATP diphosphohydrolase (EC 3.6.1.5). Biological Trace Element Research, 50: 209-219.

7. Zatta $P$, Zambenedetti $P$, Pizziuti A \& Perazollo M (1995). Different effects of aluminum upon anhydrases and $\mathrm{Na}^{+} / \mathrm{K}^{+}$ ATPase activities in rat. Neuroscience Letters, 197: 65-68.

8. Wills MR \& Savory J (1983). Aluminum poisoning. Dialysis encephalopathy, osteomalacia and anemia. Lancet, 2: 29-34.

9. Touam $M$, Martinez $F$, Lacour $B$, Bourdon R, Zingraff J , Giulio S \& Drueke T (1983). Aluminum-induced, reversible microcytic anemia in chronic renal failure: clinical experimental studies. Clinical Nephrology, 19: 295-299.

10. Mitchell RA, Drake J E, Wittin LA \& Rejent TA (1977). Erythrocyte porphobilinogen synthase (delta-aminolevulinate dehydratase) activity: A reliable and quantitative indicator of lead exposure in humans. Clinical Chemistry, 23: 105-111.

11. Oskarsson A (1989). Effects of perinatal treatment with lead and disulfiram on ALA-D activity in blood, liver and kidneys and urinary ALA excretion in rats. Pharmacology and Toxicology, 64: 344-348.

12. Rocha JBT, Freitas AJ, Marques MB, Pereira ME, Emanuelli T \& Souza DOG (1993). Effects of methylmercury exposure during the second stage of rapid postnatal brain growth on negative geotaxis and on delta-aminolevulinate dehydratase of suckling rats. Brazilian J ournal of Medical and Biological Research, 26: 1077-1083.

13. Rocha JBT, Pereira ME, Emanuelli $T$, Christofari RS \& Souza DOG (1995). Effect of treatment with mercury chloride and lead acetate during the second stage of rapid postnatal brain growth on $\delta$-aminolevulinic acid dehydratase (ALA-D) activity in brain, liver, kidney and blood of suckling rats. Toxicology, 100: 27-37.

14. Emanuelli $T$, Rocha J BT, Pereira $M E$, Porciuncula LO, Martins A, Morsch VM \& Souza DOG (1996). Effect of mercuric intoxication and dimercaprol treatment on delta-aminolevulinate dehydratase from brain, liver and kidney of adult mice. Pharmacology and Toxicology, 79: 136-143.

15. Emanuelli $T$, Rocha JBT, Pereira ME, Nascimento PC, Souza DOG \& Beber FA (1998). $\delta$-Aminolevulinate dehydratase inhibition by 2,3-dimercaptopropanol is mediated by chelation of zinc from a site involved in maintaining cysteinyl residues in a reduced state. Pharmacology and Toxicology, 83: 95-103.

16. Barbosa NVB, Rocha JBT, Zeni G, Emanuelli $\mathrm{T}$, Beque $\mathrm{MC} \&$ Braga $\mathrm{AL}$ (1998). Effect of organic forms of selenium on $\delta$-aminolevulinate dehydratase from liver, kidney and brain of adult rats. Toxicology and Applied Pharmacology, 149: 243-253.

17. Bergdahl IA, Grubb A, Schütz A, Desnick RJ , Wetmur J G, Sassa $S \&$ Skerfving S (1997). Lead binding to $\delta$-aminolevulinic acid dehydratase (ALAD) in human erythrocytes. Pharmacology and Toxicology, 81: 153-158.

18. Zaman K, Zaman W \& Siddique H (1993). Hematological and enzymatic results of aluminum intoxication in rats. Comparative Biochemistry and Physiology, 105C:
73-76.

19. Bechara EJ H, Medeiros MHG, Monteiro HP, Hermes-Lima M, Pereira B, Demasi $M$, Costa CA, Abdall DSP, Onuki J, Wendel CMA \& Masci PD (1993). A free radical hypothesis of lead poisoning and inborm porphyrias associated with 5-aminolevulinic acid overload. Química Nova, 16: 385-392.

20. Bechara EJ (1996). Oxidative stress in acute intermittent porphyria and lead poisoning may be triggered by 5-aminolevulinic acid. Brazilian J ournal of Medical and Biological Research, 29: 841-851.

21. Slanina P, Frech W, Ekström L-G, Lööf L, Slorach S \& Anders C (1986). Dietary citric acid enhances absorption of aluminum in antacids. Clinical Chemistry, 32: 539-541.

22. Bohrer DN \& Schwedt G (1993). Alumiumspurenanalyse in dialysekonzentraten. Pharmacie, 48: 676-678.

23. Sassa S (1982). $\delta$-aminolevulinic acid dehydratase assay. Enzyme, 28: 133-145.

24. Martin RB (1986). The chemistry of aluminum as related to biology and medicine. Clinical Chemistry, 32: 1797-1806.

25. Bradford M (1976). A rapid and sensitive method for quantification of microgram quantities of protein utilising the principle of protein-dye binding. Analytical Biochemistry, 72: 248-254.

26. Zaman K, Dabrowski Z, Miszta H \& Smolénski O (1990). The effect of aluminum on the heme biosynthesis (in vitro) in bone marrow cells in rats. Folia Haematologica, 117: 307-311.

27. Oteiza PI, Kleinman CG, Demasi M \& Bechara EJ (1995). 5-Aminolevulinic acid induces iron release from ferritin. Archives of Biochemistry and Biophysics, 316: 607-611.

28. Garbossa G, Galvez G, Perez G, Stripeikis J , Tudino M \& Nesse A (1998). Oral aluminum administration to rats with normal renal function: body distribution. Human and Experimental Toxicology, 16: 318-322.

29. Abreo K, J angula J , J ain SK, Sella M \& Glass J (1991). Aluminum uptake and toxicity in cultured mouse hepatocytes. J ournal of the American Society of Nephrology, 1: 1299-1304. 